\title{
KKN MANDIRI PADA MASA PANDEMI COVID-19 DENGAN TEMA PENGELOLAAN DATA DESA DI DESA SAOSINA KECAMATAN ADONARA TIMUR KABUPATEN FLORES TIMUR
}

\author{
Naima Sulaiman', Maria Helena Carolinda Dua Mea ${ }^{2 *}$ \\ ${ }_{1,2}$ Universitas Flores, Ende, Indonesia \\ *Penulis Korespondensi, email: helenaduamea@gmail.com
}

\begin{abstract}
In 2021, the University of Flores Community Service Program is carried out in the New Normal period, with students carrying out the Community Service Program independently in their respective villages. The author chose the village of Saosina, which is located on Adonara Island, which is part of the East Flores Regency area. Village data collection is not carried out optimally due to a lack of village officials, limited village facilities, and the absence of a village website. The author managed the data of Saosina village using the methods of observation, interviews, and documentation. The main work program at Independent Community Service Program in Saosina Village is to deal with issues that arise in the management of village data administration, such as data collection, input, and the creation of community documents (family cards, birth certificates, transfer letters). Outside of the theme, activities included the distribution of basic food assistance, the production of trash cans, and the cleaning of village offices. It is hoped that the Village Government will be able to continue the programs started by KKN students and apply the concept of implementing activities as done by KKN students. In the face of the digital era 4.0, the Saosina Village Government should be able to create a special website for the Saosina Village Government on the internet that contains village information and statistics about the Saosina village.
\end{abstract}

Keywords: Independent Community Service Program, East Adonara, Saosina, village data administration management, Covid-19

Abstrak. Program KKN Universitas Flores tahun 2021 dilakukan dalam masa New Normal, di mana Program KKN dilaksanakan oleh mahasiswa secara mandiri di desa asalnya masing-masing. Lokasi yang dipilih oleh penulis adalah desa Saosina yang terletak di Pulau Adonara yang masuk dalam wilayah Kabupaten Flores Timur. Terbatasnya jumlah aparat desa dan terbatasnya fasilitas desa serta belum adanya website desa membuat pendataan desa belum dilakukan secara optimal. Metode observasi, wawancara, dan dokumentasi adalah metode yang digunakan penulis dalam melakukan pengelolaan data desa Saosina. Program kerja utama dalam KKN Mandiri di Desa Saosina ini adalah menangani permasalahan yang terjadi pada pengelolaan administrasi data desa yaitu pendataan, penginputan, pembuatan dokumen-dokumen masyarakat (kartu keluarga, akta kelahiran, surat pindah). Kegiatan-kegiatan yang dilakukan di luar tema adalah pendistribusian bantuan sembako, pembuatan tempat sampah, dan pembersihan kantor desa. Diharapkan Pemerintah Desa dapat melanjutkan program-program yang telah dirintis oleh mahasiswa KKN serta dapat menerapkan konsep pelaksanaan kegiatan sebagaimana yang telah dilakukan oleh mahasiswa KKN. Menghadapi era digital 4.0, Pemerintah Desa Saosina sebaiknya dapat membuat laman khusus Pemerintah Desa Saosina di internet yang memuat informasi desa dan statisik desa Saosina.

Kata Kunci: KKN Mandiri, Adonara Timur, Saosina, Pengelolaan data desa, Covid-19

How to Cite: Sulaiman, N., \& Mea, M. H. C. D. (2021). KKN Mandiri pada Masa Pandemi Covid-19 dengan Tema Pengelolaan Data Desa di Desa Saosina Kecamatan Adonara Timur Kabupaten Flores Timur.Mitra Mahajana: Jurnal Pengabdian Masyarakat, 2(3), 241-249. doi: https://doi.org/10.37478/mahajana.v2i3.1253

\section{PENDAHULUAN}

Program KKN merupakan salah satu bentuk pengabdian kepada masyarakat yang dilakukan oleh mahasiswa sebagai salah satu wujud implementasi Tri Dharma Perguruan Tinggi. Program KKN Universitas Flores tahun 2021 dilakukan dalam masa New Normal, di mana Program KKN dilaksanakan oleh mahasiswa secara mandiri di desa asalnya masingmasing dengan tetap memperhatikan protokol kesehatan disetiap kegiatan. Program kerja utama dalam KKN bertema Pengelolaan data desa ini adalah menangani permasalahan yang terjadi pada pengelolaan administrasi data desa (Jupri et al., 2021)(Siregar \& Sundari, 2016) (Arfian, 2018) (Nafidah \& Anisa, 2017). Lokasi yang dipilih oleh penulis adalah desa Saosina yang terletak di Pulau Adonara yang masuk dalam wilayah Kabupaten Flores Timur. 
Desa Saosina adalah salah satu desa dari 19 desa dan 2 kelurahan dalam wilayah kecamatan Adonara Timur. Kecamatan Adonara Timur dibentuk berdasarkan peraturan pemerintah No.29 tahun 1992. Desa Saosina pada mulanya adalah bagian dari Desa Narasaosina, akibat dari penambahan penduduk dan besarnya wilayah Desa Narasaosina maka dibuatlah pemekaran dan dibagi menjadi dua desa. Desa Saosina dimekarkan pada tanggal 11 Oktober 2010. Penduduk Desa Saosina terdiri dari tiga suku (disebut dengan lewo) yaitu Geko, Lamalimut dan Lamagewok. Berdasarkan data dari Pemerintah Desa jumlah penduduk Desa Saosina dari bulan Januari sampai dengan bulan Agustus 2021 adalah 912 jiwa dengan 192 Kepala Keluarga. Penduduk Desa Saosina sebagian besar berprofesi sebagai petani, ASN, dan wiraswasta.

Secara geografis, batas- batas Desa Saosina adalah sebelah Utara dengan Desa Horowura Kecamatan Adonara Tengah, sebelah Selatan dengan Desa Waiburak, sebelah Timur dengan Desa Narasaosina, dan seebelah Barat dengan Kelurahan Waiwerang Kota. Luas wilayah Desa Saosina adalah $335 \mathrm{Km} 2$ atau $350.000 \mathrm{Ha}$, dengan topografi Desa terdiri atas daratan, lembah dan perbukitan. Untuk mempermudah urusan dan pembangunan Desa maka Pemerintah Desa Saosina dibagi dalam beberapa wilayah Dusun dan RT yaitu Dusun I Kampung Baru, terdiri atas empat RT (RT.001, RT.002, RT.003 dan RT 004), dan Dusun II Lamalimut, terdiri atas empat RT (RT.005, RT.006 Kukung Pahade, RT.007 Beronjong, dan RT.008 Lamalimut-Terong Tanah). Komoditi unggulan desa Saosina adalah kopra, jambu mete, coklat, kemiri, dan jagung.

Penduduk di desa Saosina mayoritas beragama Islam dan Katolik dan hidup berdampingan. Masyarakat sangat menjunjung tinggi rasa persaudaraan sehingga terciptanya suasana kehidupan yang aman dan damai. Terdapat satu pos kesehatan desa yang memberikan pelayanan kesehatan terhadap warga setempat. Saat ini semua rumah sudah memiliki sambungan listrik. Untuk berkomunikasi ke luar desa warga desa Saosina menggunakan telepon genggam yang sudah terhubung dengan jaringan internet.

Permasalahan yang ditemui oleh penulis di lokasi pengadian adalah masih banyaknya penduduk desa yang belum terdata, karena belum memiliki kelengkapan administrasi seperti Kartu Keluarga, KTP, Akta Kelahiran, dan Akta Kematian. Terdapat 47 orang penduduk desa Saosina yang belum memiliki KTP, 9 orang belum memiliki akta kelahiran dan 2 orang belum memiliki akta kematian. Selain itu terdapat 15 keluarga yang tidak memiliki Kartu Keluarga karena belum resmi menikah. Terbatasnya jumlah aparat desa dan terbatasnya fasilitas desa serta belum adanya website desa membuat pendataan desa belum dilakukan secara optimal. Diharapkan dengan kegiatan KKN Mandiri dengan tema Pengelolaan Data Desa ini dapat membantu aparat desa Saosina dalam melakukan pendataan penduduk desa.

\section{METODE PELAKSANAAN}

Kegiatan KKN Mandiri Pengelolaan Data Desa ini dilakukan dengan beberapa metode yaitu:

1) Metode Observasi

Metode observasi atau pengamatan adalah alat pengumpulan data yang dilakukan dengan cara mengamati dan mencatat secara sistematik gejala-gejala yang ada di tempat penelitian (Zakky, 2020). Pada metode pengamatan ini, penulis mengamati secara langsung fenomena-fenomena sosial yang terjadi di lokasi.

2) Metode Interview

Metode ini disebut juga dengan metode wawancara, yaitu suatu metode pengumpulan data yang dilakukan melalui tanya jawab secara langsung dengan sumber (Nursalam, 2016 \& Fallis, 2013). Wawancara secara mendalam ini dilakukan oleh peneliti terhadap informan yang menjadi obyek dari kegiatan ini yaitu PEMDes dan BKD. Wawancara ini bertujuan untuk memperoleh informasi tentang administrasi desa yang belum dikerjakan serta kendala yang dihadapi dalam manajemen data desa.

3) Metode Dokumentasi

Dalam penelitian kualitatif terdapat sumber data yang berasal dari manusia seperti dokumen berupa foto dan bahan statistic (Maulida, 2020). Dokumentasi yang 
diperlukan dalam penelitian ini meliputi seluruh rangkaian kegiatan kegiatan KKN Mandiri mulai dari penerimaan oleh Pemdes sampai kegiatan terakhir KKN Mandiri. Kegiatan KKN Mandri ini dilakukan melalui beberapa tahap seperti tahap persiapan, pelaksanaan program, serta monitoring.

1) Tahap Persiapan

Sebelum memulai kegiatan KKN Mandiri, maka penulis mengikuti kegiatan pembekalan serta menyiapkan administrasi berupa surat pengantar KKN dan izin kepada kepala desa untuk melakukan kegiatan KKN di desa Saosina.

2) Pelaksanaan Program

Pada kegiatan ini kami menjalankan program kerja yang sudah ditetapkan dengan persetujuan Pemerintah Desa.

3) Monitoring

Dilakukan dengan cara memastikan program kerja yang dilakukan berjalan dengan efektif atau tidak dengan membuat laporan mingguan.

\section{HASIL DAN PEMBAHASAN}

Program kerja utama dalam KKN Mandiri di Desa Saosina ini adalah menangani permasalahan yang terjadi pada pengelolaan administrasi data desa yaitu pendataan, penginputan, pembuatan dokumen-dokumen masyarakat (kartu keluarga, akta kelahiran, surat pindah). Kegiatan-kegiatan yang dilakukan di luar tema adalah pendistribusian bantuan sembako, pembuatan tempat sampah, dan pembersihan kantor desa.

Kegiatan KKN Mandiri-Pengelolaan Data Desa diawali dengan kegiatan persiapan yakni pembekalan oleh LP3KKN dan menyiapkan surat-surat ijin. Karena masih dalam masa pandemi Covid-19 maka kegiatan pembekalan dilaksanakan secara daring selama dua hari pada tanggal 2 dan 3 Agustus 2021. Materi pembekalan pada hari pertama meliputi materi umum yang berkaitan dengan kehidupan bermasyarakat, aspek social, budaya serta sistematika laporan akhir. Materi pembekalan hari kedua meliputi materi khusus yang berkaitan dengan tema yang dipilih oleh penulis, yaitu manajemen data desa.

Kegiatan KKN Mandiri mulai resmi dijalankan sejak tanggal 4 Agustus 2021. Pada hari tersebut, penulis telah berada pada lokasi pengabdian dan diterima dengan baik oleh Pemerintah Desa Saosina.

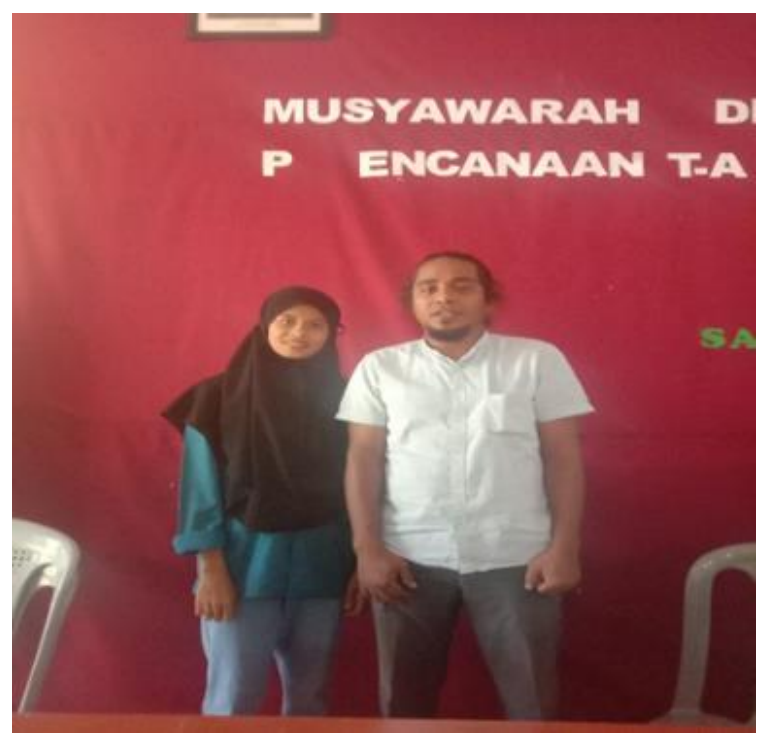

Gbr.1 Penerimaan oleh Kepala Desa Saosina

Selanjutnya pelaksanaan kegiatan KKN Mandiri-Pengelolaan Data Desa diuraikan dalam tabel di bawah ini: 
Tabel 1. Rincian Program KKN Mandiri Pengelolaan Data Desa Saosina

\begin{tabular}{cll}
\hline No & \multicolumn{1}{c}{ Jenis Kegiatan } \\
\hline 1 & Rabu 5 Agustus 2021 \\
Melakukan pendataan awal penduduk. \\
Data yang tersedia pada Kantor Desa tidak akurat, sehingga penulis harus melakukan wawancara, \\
observasi dan dokumentasi secara langsung kepada penduduk.
\end{tabular}

2 Kamis, 6 Agustus 2021

Pengisian formulir pembuatan akta kelahiran dan pembuatan surat pindah penduduk.

Penduduk yang belum memiliki akta kelahiran diharuskan mengisi formulir pendaftaran pembuatan akta, terkadang mereka harus dibantu dalam pengisian formulir untuk meminimalisir kesalahan dalam pengisian fomulir. Banyaknya perpindahan penduduk ke luar desa yang tidak tercatat juga mempengaruhi administrasi desa sehingga penulis melakukan rekap data pindah dan membuat surat keterangan pindah penduduk.
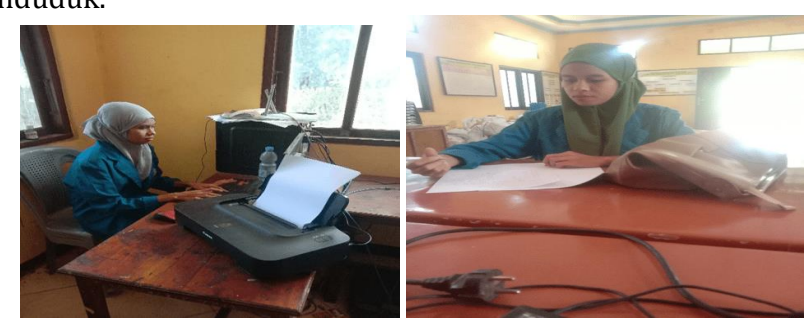

Gbr 4. Pengetikan surat pindah penduduk, Gbr 5. Mengisi formulir akta kelahiran

3 Senin, 9 Agustus 2021

Membantu desa menghitung pajak daerah.

Terbatasnya jumlah staf kantor desa Saosina mempengaruhi kinerja perhitungan pajak daerah. Penulis melakukan perhitungan pajak daeah selain untuk membantu Pemerintah Desa juga untuk mempraktekan teori pajak yang sudah dipelajari.

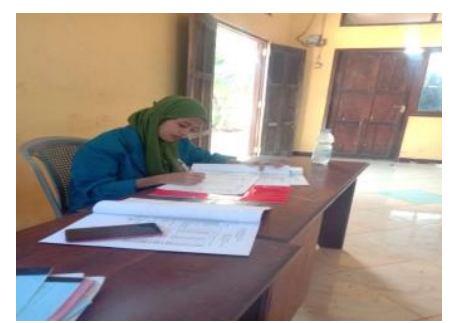

Gbr 6. Perhitungan pajak daerah

\section{$4 \quad$ Kamis, 12 Agustus 2021}

Menghitung pajak Bumi dan Bangunan masyarakat desa Saosina tahun 2021 didampingi aparat desa selain untuk membantu Pemerintah Desa juga untuk mempraktekan teori dari mata kuliah Perpajakan pada Program Studi Akuntansi Universitas Flores.

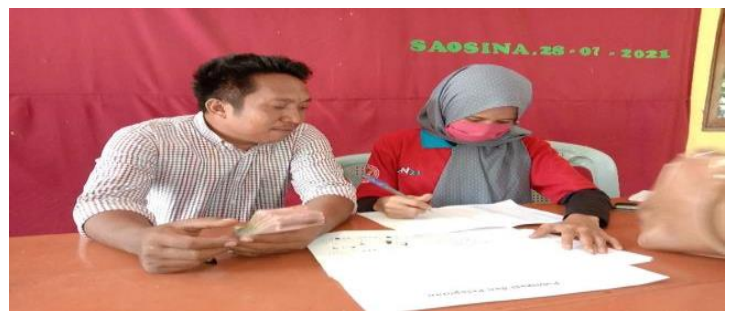

Gbr 7. Menghitung PBB Bersama aparat desa 


\section{$5 \quad$ Kamis, 12 Agustus 2021}

Menyusun profil desa berbasis SDGs.

SDGs atau Sustainable Development Goals Desa adalah upaya terpadu mewujudkan Desa tanpa kemiskinan dan kelaparan, Desa ekonomi tumbuh merata, Desa peduli kesehatan, Desa peduli lingkungan, Desa peduli pendidikan, Desa ramah perempuan, Desa berjejaring, dan Desa tanggap budaya untuk percepatan pencapaian Tujuan Pembangunan Berkelanjutan. SDGs Desa merupakan role pembangunan berkelanjutan yang akan masuk dalam program prioritas penggunaan Dana Desa Tahun 2021 (https://www.mekarlaksana-ciparay.desa.id/artikel/2021/4/27/sosialisasi-dan-pembekalan-relawanpendataan-sdgs-desa-tahun-2021), (https://sdgsdesa.kemendesa.go.id/pemutakhiran-data-sdgs-desa/).

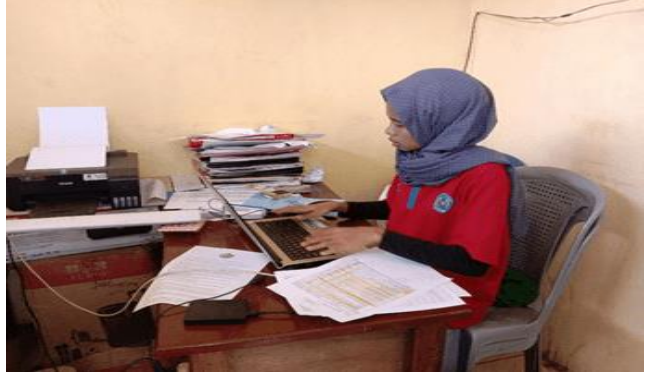

Gbr 8. Penyusunan profil desa

\section{Jumad, 13 Agustus 2021}

Membuat laporan penggunaan dana desa semester satu tahun anggaran 2021.

Penggunaan Alokasi Dana Desa yang diterima pemerintah desa 30\% alokasi dana desa dipergunakan untuk operasional penyelenggaraan pemerintah desa dalam pembiayaan operasional desa, biaya operasional BPD, biaya operasional tim penyelenggara alokasi dana desa. Sedangkan $70 \%$ dana desa dipergunakan untuk pemberdayaan masyarakat dalam pembangunan sarana dan prasarana ekonomi desa, pemberdayaan dibidang pendidikan, kesehatan, pemberdayaan ekonomi masyarakat terutama untuk mengentaskan kemiskinan dan bantuan keuangan kepala lembaga masyarakat desa, BUMDes, kelompok usaha sesuai potensi ekonomi masyarakat desa, serta bantuan keuangan kepada lembaga yang ada di desa seperti LPMD, RT, RW, PKK, Karang Taruna, Linmas. (https://djpb.kemenkeu.go.id/kppn/bukittinggi/id/data-publikasi/artikel/2951-dana-desa-pengertian,sumber-dana,-penyaluran-dana,-dan-prioritasnya.html).

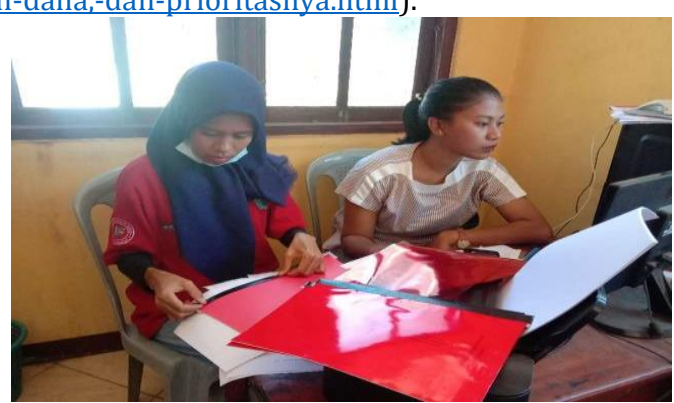

Gbr 9. Penyusunan laporan dana desa semester 1 TA 2021

\section{$6 \quad$ Kamis, 19 Agustus 2021}

Penginputan data IDM (Indeks Desa Membangun dan penginputan data penduduk berbasis SIKS -NG (KK yang mendapat bantuan berupa PKH, UMKM, dan BST).

Indeks Desa Membangun (IDM) merupakan Indeks Komposit yang dibentuk berdasarkan tiga indeks, yaitu : Indeks Ketahanan Sosial (Pendidikan, Kesehatan, Modal Sosial, Permukiman), Indeks Ketahanan Ekonomi (Keragaman Produksi Masyarakat, Akses Pusat Perdagangan dan Pasar, Akses Logistik, Akses Perbankan dan Kredit, Keterbukaan Wilayah), Indeks Ketahanan Ekologi / Lingkungan (Kualitas Lingkungan, Bencana Alam, Tanggap Bencana). (https://idm.kemendesa.go.id/view/detil/1/tentang-
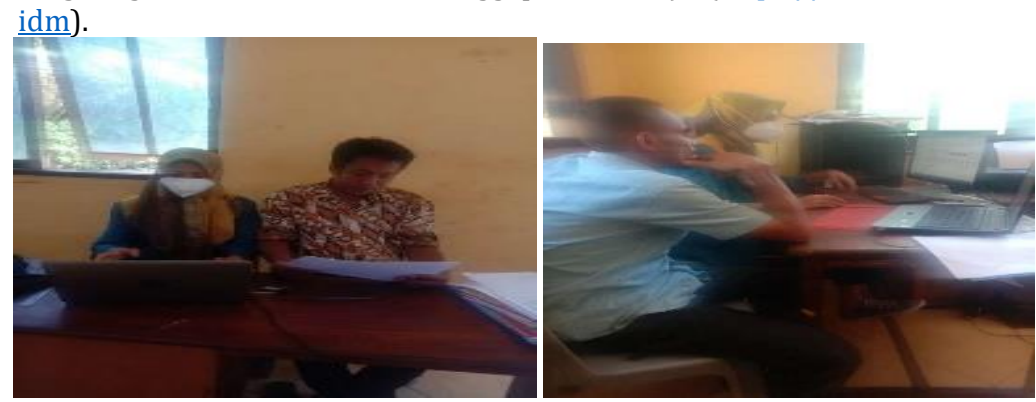

Gbr 10\&11. Penginputan data desa 


\section{Selasa, 23 Agustus 2021}

Melakukan perbaikan data dalam Kartu Keluarga, dan membantu kegiatan verifikasi surat permintaan pembayaran (SPP) dari kepala seksi.

Surat Permintaan Pembayaran (SPP) adalah dokumen pengajuan untuk mendanai kegiatan pengadaan barang dan jasa. Pengajuan SPP untuk kegiatan yang seluruhnya dilaksanakan melalui penyedia barang/jasa dilakukan setelah barang/jasa diterima. SPP diajukan oleh Kaur/Kasi dengan melampirkan pernyataan tanggungjawab belanja (PTB) dan bukti penerimaan barang/jasa di tempat, SPP ini kemudian dilakukan Verifikasi oleh Sekretaris Desa, selanjutnya disetujui untuk dibayarkan oleh Kepala Desa, baru kemudian dibayar lunas oleh Kaur Keuangan. Kepala Desa menyetujui permintaan pembayaran sesuai dengan hasil verifikasi yang dilakukan oleh sekretaris Desa. Kaur Keuangan melakukan pencairan anggaran sesuai dengan besaran yang tertera dalam SPP setelah mendapatkan persetujuan dari kepala Desa (https://mediadesa.org/surat-permintaan-pembayaran-spp/).

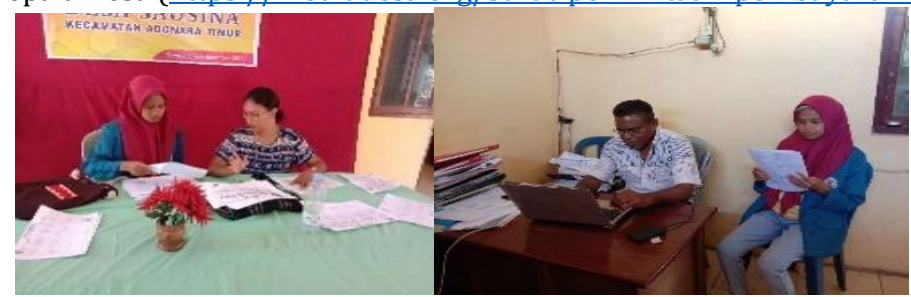

Gbr 12\&13. Perbaikan data Kartu Keluarga dan verifikasi SPP

Kegiatan-kegiatan selain pengelolaan data desa tetap dilakukan sebagai bentuk karya pengabdian pada masyarakat, sebagai berikut:

\section{1) Kegiatan Bakti Sosial bagi para Korban Bencana Banjir}

Bencana banjir bandang di Pulau Adonara pada tanggal 4 april 2021 lalu yang menyebabkan banyak korban jiwa merupakan peristiwa yang sangat berpengaruh terhadap semua aspek kehidupan masyarakat di Kecamatan Adonara, terutama aspek perekonomian. Ditambah lagi dengan situasi pandemi Covid-19 yang mempengaruhi semua aspek kehidupan masyarakat. Saat ini pemerintah daerah dengan dukungan dari pemerintah provinsi NTT dan pemerintah pusat terus melakukan perbaikan infrastruktur dan fasilitas umum yang rusak, sambil terus mendukung warga yang terdampak dengan bantuan dan subsidi-subsidi dengan harapan agar perekonomian masyarakat di Pulau Adonara segera pulih. Pemerintah Desa Saosina secara intens melakukan kegiatan bakti sosial bagi warga yang terdampak bencana banjir bandang. Bakti sosial atau lebih dikenal dengan baksos merupakan salah satu kegiatan hasil dari rasa kemanusiaan yang timbul untuk sesama (Mutmainnah et al., 2020). Kegiatan bakti sosial ini dijalankan pada minggu pertama kegiatan KKN Mandiri.
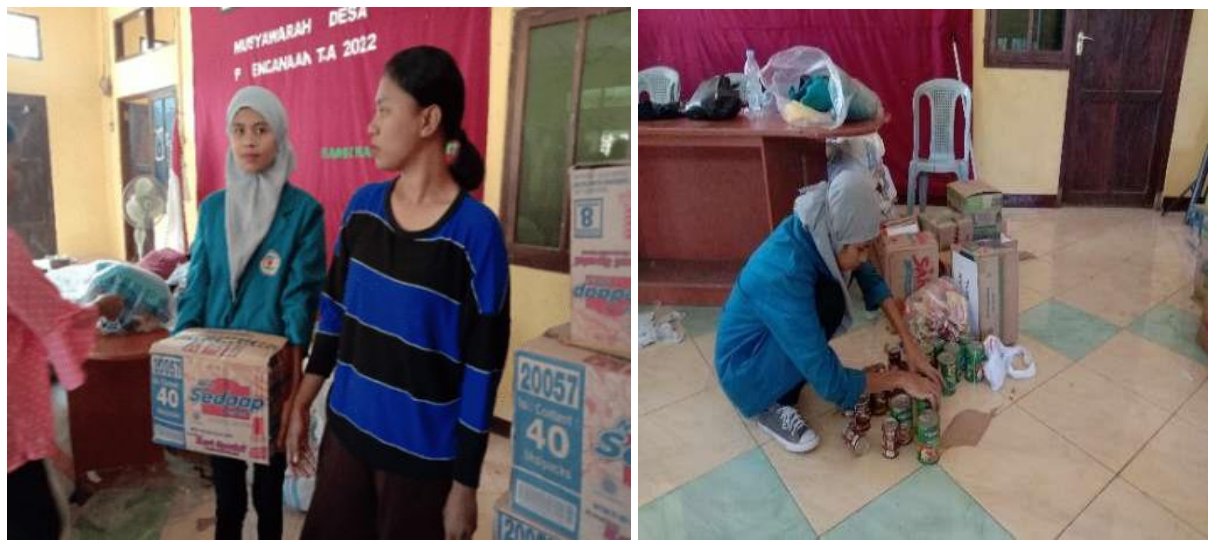

Gambar 14 \& 15. Bakti Sosial 
2) Kegiatan kerja bakti

Tujuan dari kegiatan pengabdian masyarakat dengan kerja bakti ini antara lain mengkampanyekan pentingnya kebersihan lingkungan terhadap masyarakat, membantu mengatasi permasalahan kebersihan lingkungan di masyarakat, serta dapat melatih mahasiswa untuk memiliki sikap kepedulian terhadap alam dan lingkungan, serta mewujudkan Tri Dharma Perguruan Tinggi (Khairunnisa, Ilham Syahrul Jiwandono, Nurhasanah, Nurul Kemala Dewi, Heri Hadi Saputra, 2019; Mea, 2020).

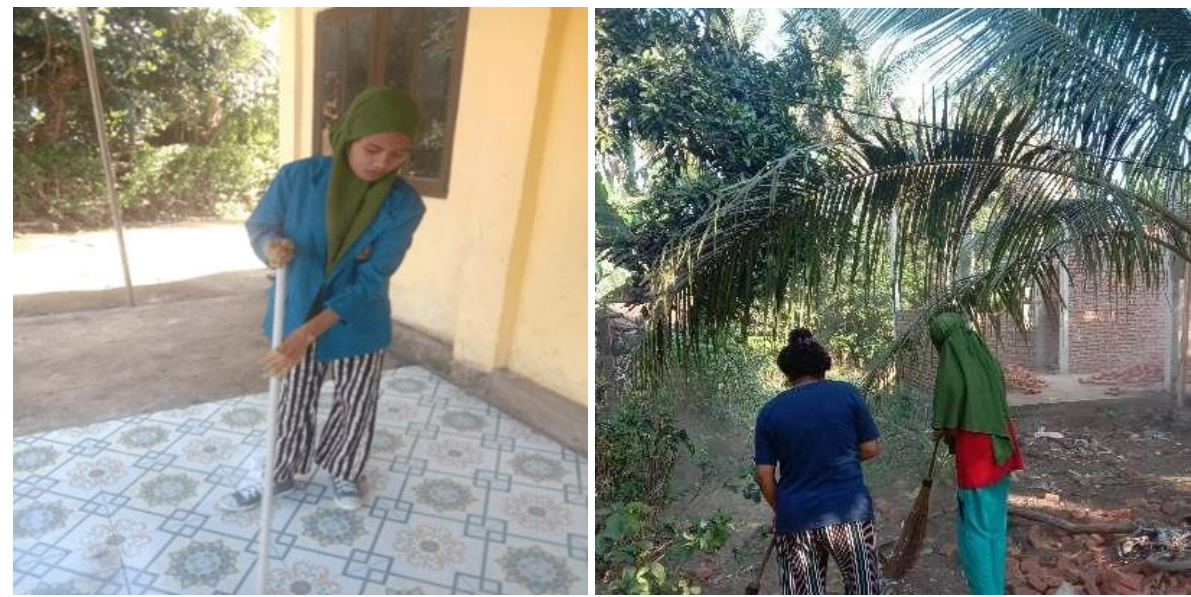

Gambar 16\&17. Kegiatan Kerja Bakti

3) Pembuatan tempat sampah

Kebersihan lingkungan dan kebersihan diri adalah faktor utama dalam mewujudkan masyarakat yang sehat. Pengelolaan sampah menjadi salah satu permasalahan yang dihadapi dalam menciptakan, menjaga, dan meningkatkan kebersihan lingkungan (Irawati et al., 2019). Pengetahuan serta kesadaran tentang hidup bersih dan sehat bebas sampah sangat penting bagi masyarakat tidak hanya di kota tetapi juga di desa (Sari \& Umama, 2019). Kurangnya kesadaran masyarakat untuk menjaga kebersihan lingkungan di Desa Saosina masih rendah diamati dari sampah yang berserakan di lingkungan serta tidak tersedianya tempat sampah di rumah maupun di tempat umum. Salah satu yang dilaksanakan dalam pelaksanaan program ini adalah pengadaan tempat sampah dengan memanfaatkan bahan yang ada di alam desa yaitu bambu, disebut Patsambu (Tempat Sampah Bambu).

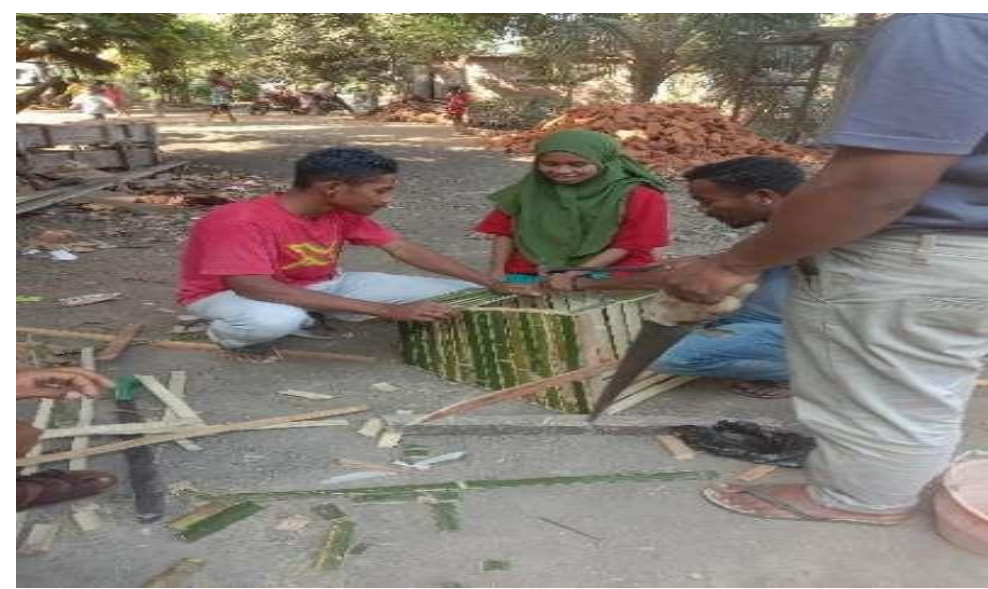

Gambar 18. Pembuatan tempat sampah 
Dari pelaksanaan kegiatan tersebut dilakukan kegiatan monitoring dalam tahapan kegiatan KKN Mandiri-Pengelolaan Data Desa. Kegiatan-kegiatan tersebut dilaporkan tertulis secara daring pada setiap akhir minggu, dilengkapi dengan dokumentasi berupa foto dan video kegiatan. Pada akhir kegiatan KKN Mandiri dilakukan pembuatan Laporan Akhir yang disahkan oleh Pemerintah Desa dan Universitas Flores.

\section{SIMPULAN DAN TINDAK LANJUT}

Kegiatan yang sudah dilakukan selama satu bulan yang berkaitan dengan tema pengelolaan data desa adalah pendataan, penginputan, pembuatan dokumen-dokumen masyarakat (kartu keluarga, akta kelahiran). Semua program kerja hampir dapat dilaksanakan dengan baik walaupun ada beberapa kendala karena situasi dan kondisi di lokasi yang berubah-ubah yang menyesuaikan dengan kebutuhan desa Saosina dan instruksi Pemerintah Desa. Situasi pandemi covid-19 yang masih berlangsung juga berpengaruh terhadap pelaksanaan kegiatan sehingga tidak ada kegiatan di luar kantor desa yang melibatkan kerumunan warga. Kegiatan-kegiatan yang dilakukan di luar tema adalah membantu pendistribusian sembako pada para korban bencana alam, pembuatan tempat sampah, dan membersihkan kantor desa.

Diharapkan Pemerintah Desa dapat melanjutkan program-program yang telah dirintis oleh mahasiswa KKN serta dapat menerapkan konsep pelaksanaan kegiatan sebagaimana yang telah dilakukan oleh mahasiswa KKN. Menghadapi era digital 4.0, Pemerintah Desa Saosina sebaiknya dapat membuat laman khusus Pemerintah Desa Saosina di internet yang memuat informasi desa dan statisik desa Saosina.

\section{DAFTAR PUSTAKA}

Arfian, A. (2018). Implementasi Aplikasi Sistem Demografi berbasis Green Computing dalam Pengelolaan Data Kependudukan Desa Kertarahayu Kecamatan Setu Kabupaten Bekasi. Applied Information System and Management (AISM), 1(1). https://doi.org/10.15408/aism.v1i1.8673

https://www.mekarlaksana-ciparay.desa.id/artikel/2021/4/27/sosialisasi-dan-pembekalanrelawan-pendataan-sdgs-desa-tahun-2021

https://sdgsdesa.kemendesa.go.id/pemutakhiran-data-sdgs-desa/

https://djpb.kemenkeu.go.id/kppn/bukittinggi/id/data-publikasi/artikel/2951-dana-desapengertian,-sumber-dana,-penyaluran-dana,-dan-prioritasnya.html

https://idm.kemendesa.go.id/view/detil/1/tentang-idm

\section{https://mediadesa.org/surat-permintaan-pembayaran-spp/}

Irawati, D. Y., B, Y. H., \& Marcella, O. (2019). Peningkatan Lingkungan Bersih dan Sehat di Kampung Kalisari Timur I, Surabaya. Jurnal Bakti Saintek: Jurnal Pengabdian Masyarakat Bidang Sains Dan Teknologi, 3(2). https://doi.org/10.14421/jbs.1514

Jupri, A., Prasedya, E. S., Rozi, T., Hipzi, A. A., \& Abdat, H. (2021). KKN Era New Normal Aktifasi Website SID dan Penanganan Masalah Administrasi Data Penduduk Desa Labuhan Haji. https://doi.org/10.29303/jpmpi.v3i2.923

Khairunnisa, Ilham Syahrul Jiwandono, Nurhasanah1, Nurul Kemala Dewi, Heri Hadi Saputra, T. L. W. (2019). Kampanye Kebersihan Lingkungan Melalui Program Kerja Bakti Membangun Desa Di Lombok Utara. Jurnal Pendidikan Dan Pengabdian Masyarakat.

Maulida. (2020). TEKNIK PENGUMPULAN DATA DALAM METODOLOGI PENELITIAN. Darussalam, 21.

Mea, M. H. C. D. (2020). KAMPANYE KEBERSIHAN LINGKUNGAN MELALUI PROGRAM KERJA BAKTI MAHASISWA PROGRAM STUDI MANAJEMEN DI KELURAHAN POTULANDO, 
KECAMATAN ENDE TENGAH, KABUPATEN ENDE. Mitra Mahajana: Jurnal Pengabdian Masyarakat, 1(1). https://doi.org/10.37478/mahajana.v1i1.719

Mutmainnah, M., Widodo, A. S., Dimyati, A., Dhiani, H. P., \& Wardani, S. (2020). APLIKASI SOCIAL RESPONSIBILITY: KEGIATAN BAKTI SOSIAL DALAM MASA PANDEMI COVID-19 DI KELURAHAN KUKUSAN RT 06 RW 05 KECAMATAN BEJI KOTA DEPOK JAWA BARAT 16425. DEDIKASI PKM, 1(3). https://doi.org/10.32493/dedikasipkm.v1i3.6682

Nafidah, L. N., \& Anisa, N. (2017). Akuntabilitas Pengelolaan Keuangan Desa di Kabupaten Jombang. Akuntabilitas, 10(2). https://doi.org/10.15408/akt.v10i2.5936

Nursalam, 2016, metode penelitian, \& Fallis, A. G. (2013). Metode Penelitian Wawancara. Journal of Chemical Information and Modeling, 53(9).

Sari, M. M., \& Umama, H. A. (2019). Patsambu (Tempat Sampah Bambu) Untuk Peningkatan Kualitas Hidup Bersih Dan Sehat Masyarakat Di Desa Talaga, Kecamatan Mancak, Serang. KAIBON ABHINAYA: JURNAL PENGABDIAN MASYARAKAT, 1(2). https://doi.org/10.30656/ka.v1i2.1537

Siregar, S. R. S., \& Sundari, P. (2016). Rancangan Sistem Informasi Pengelolaan Data Kependudukan Desa ( Studi Kasus di Kantor Desa Sangiang Kecamatan Sepatan Timur ). Sisfotek Global, 6(1).

Zakky. (2020). Pengertian Observasi Menurut Para Ahli dan Secara Umum [Lengkap]. Www.Zonareferensi.Com. 